\title{
David French 30 May 1933 to 19 March 2017
}

\author{
Stephen Mitchell \\ Chairman, British Institute at Ankara, UK \\ biaa@britac.ac.uk
}

$\mathrm{B}_{\mathrm{B}}^{\mathrm{o}}$ orn in 1933, David Henry French was the son of an East Yorkshire policeman. His mother and elder brother were killed on 8 May 1941, during the blitz on Hull. David was pulled alive from the wreckage. He was brought up by his father, with whom he was close, and an aunt, and became a funded pupil at Pocklington School. The support of a committed teacher helped him gain a place to study Classics at St Catharine's College, Cambridge, where he graduated in 1955.

After graduating, he travelled in Europe, ending up in Athens in the winter of $1955 / 1956$, but did not live at the British School at Athens (BSA), preferring to lodge with a Greek family to acquire modern Greek. Through the BSA, he met a diverse range of students and senior scholars, notably for him Dick Hope Simpson with whom he travelled further, particularly in the islands and in Laconia, and also Alan Wace for whom his wide interests and acumen were a delight. He was thus invited to join the study season on Mycenae material that summer. Here he worked with Wace's daughter Elizabeth (Lisa) who had already taken part in several seasons of excavations with her father and had trained in archaeological conservation and photography. They married in 1959, establishing a long-lasting cooperation in both fieldwork and research.

In 1957, he returned to Cambridge to take the diploma in Classical Archaeology before becoming senior fellow of the British Institute of Archaeology at Ankara (BIAA) in 1959. He excavated widely, not only at Gordion and Hacilar in Turkey, but also at Pylos and Aghios Stephanos in Greece, Nimrud and sites in the southern marshes of Iraq and in Jordan, as well as carrying out field surveys in both western Turkey and in northern Greece.

In 1961, he embarked on two new enterprises. At the suggestion of Michael Gough, then director of the BIAA, he undertook a $\mathrm{PhD}$ at Cambridge on Anatolia and the Aegean in the Third Millennium $B C$, as well as beginning the excavation of Can Hasan in the southern half of the Konya plain, a site with a heavy coverage of distinctive Early Chalcolithic pottery, which he, Jimmy Mellaart and Alan Hall recorded in 1957, the same year as they discovered Çatalhöyük. His

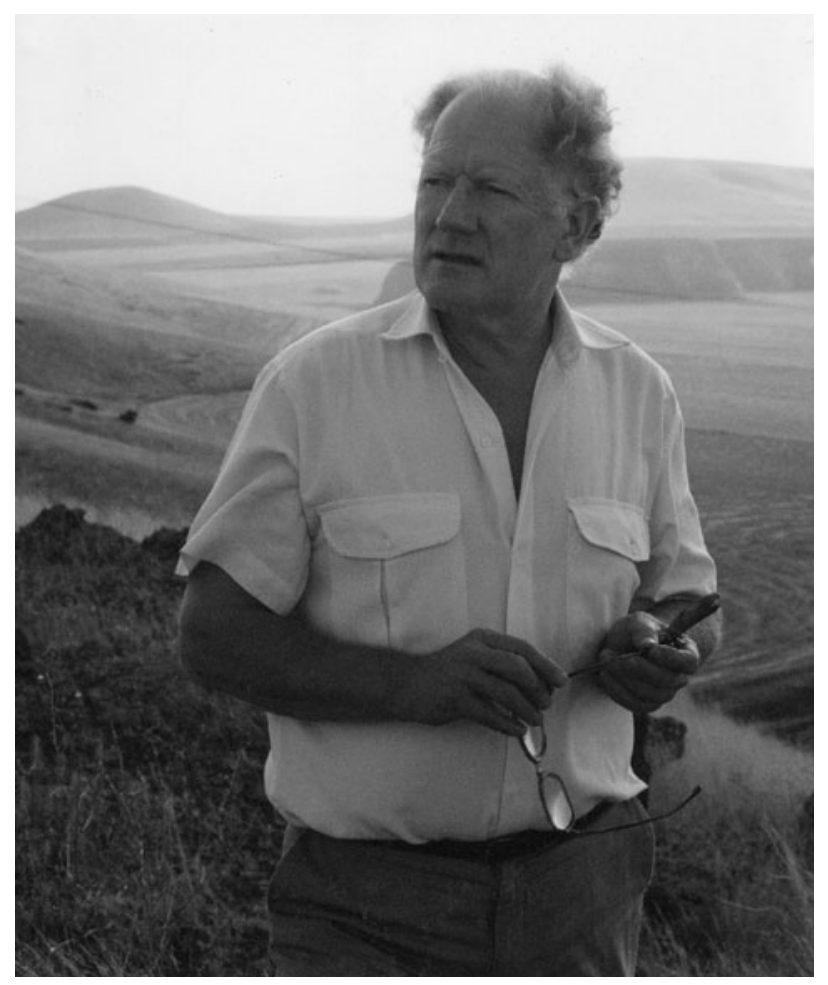

Photograph by Tuğrul Çakar, ca 1990.

time in Cambridge brought him into contact with the young generation of 'new archaeologists' from the Faculty of Archaeology and Anthropology, including Sebastian Payne, who joined the Can Hasan team. From 1967 he collaborated with the British Academy Early Agriculture Project, which was based in Cambridge, and developed techniques for recovering environmental material. He introduced flotation to retrieve grain samples and experimented with an air dome, to maintain moisture levels and to avoid fluctuation of temperature. These techniques were adapted to enhance the rescue work in the Keban Project.

Earlier, in 1966, he and his friend and colleague Harald Hauptmann had prospected sites on the Aegean coast of Turkey with the aim of starting a research excavation to answer the questions relating to the Early Bronze Age which had been worrying both of them. However, by 1968 
when he took over as director of the BIAA after Michael Gough's move to Canada, both the BIAA and the Deutsches Archäologisches Institut, where Hauptmann was now director, had accepted the invitation of the Middle East Technical University to assist in the Keban Project. Thus rescue excavation had to take precedence over research excavation. To that, David was never able to return.

David French's field research on prehistoric Anatolia during the late 1950s and the 1960s was ground-breaking. His systematic work in Balıkesir, Manisa, İznik, Konya and Karaman introduced a consistent standardised methodology for survey and pottery classification that is still in use today. This early work not only demonstrates his detailed knowledge of the material cultures of prehistoric Anatolia, but also a striking ability to identify broader, underlying patterns of regional diversity and exchange. David had a vivid interest in the archaeological and natural landscapes beyond the excavated trenches, and in the relation between human communities and their natural environments. $\mathrm{He}$ had an extraordinary ability to relate sites to their environment by observing and making sense of barely perceptible details, which provided clues to understanding the larger picture. It is no surprise that his sport at Cambridge had been rifle shooting, for which he won a half-blue. A keen eye and absolute precision of execution were the hallmarks of his archaeological field skills.

The excavations at Can Hasan were designed as a complement and in some respects a corrective to the more famous excavation of Çatalhöyük, directed by his older colleague James Mellaart. Both scholars were tenacious field workers but fundamentally different in their temperament and intellectual approach. In sharp contrast to Mellaart, French combined his brilliant skills of field observation with an ascetic style of publication, in which he rigorously distinguished between the accurate and precise recording of primary data and the articulation of interpretative hypotheses.

He became director of the British Institute at Ankara at the age of 35 in 1968 and held the position for 26 years. In the same year, he became involved in the international efforts to carry out rescue excavations of sites that were due to be flooded by the Keban Dam in the Firat and Murat valleys. Four separate mounds, covering a timespan from $5000 \mathrm{BC}$ to $\mathrm{AD} 1400$, were excavated at the village of Aşvan on the southern bank of the Murat river. David's multidisciplinary concept for the Aşvan project drew inspiration from Robert Braidwood's excavations in northern Mesopotamia and the work of Eric Higgs' early agriculture team at Cambridge. Specialists carried out detailed studies of the contemporary village and its environment, including work on architecture and settlement planning, agriculture and animal husbandry. Samples of cereals, cultivated crops and the wild flora were collected by a botanical team, led by another great field scientist, Gordon Hillman, and the excavators used water-sieving (flotation) to collect carbonised grain samples on a large scale for the first time on an Anatolian site. The final archaeobotanical results have been published as a BIAA monograph in 2017.

The Aşvan project finished in 1973, and was followed during the 1980s by another rescue excavation on the western bank of the Euphrates at Tille Höyük near Adryaman. The conditions at Tille, including tense relationships with a largely Kurdish village, were not so favourable for a comprehensive environmental study, and the excavations concentrated on reconstructing the architecture and material history of the settlement mound, beginning in the Early Bronze Age and ending in the Medieval period. The most important discoveries related to the first millennium BC. Stuart Blaylock's recent monumental publications demonstrate the role played by Tille as a regional centre in the Assyrian and Achaemenid periods, and provide a bedrock for understanding the chronology and material culture of the Euphrates border region during the Iron Age.

French's high standards as an excavator attracted younger archaeologists to work with him. The care and accuracy of his excavations were legendary. The trench digging that he supervised was as immaculate as the crisp outfits that he wore amid the heat, dust and sweat of excavation in a blazing Anatolian summer. His site directors and other team members, including Anthony McNicoll and Stephen Mitchell at Aşvan, John Moore, Geoffrey Summers, Stuart Blaylock and Shahina Farid at Tille, took responsibility for publishing the rescue projects and subsequently developed important careers of their own in field archaeology.

From the early 1970s French's own research interests took an unexpected new turn. Following an encounter near Beypazarı with a villager who told David that the track he was on led to Istanbul, he investigated the whole length of the so-called Pilgrim's Road, from Istanbul to Antakya. This hobby interest grew into a comprehensive study, based on fieldwork in every corner of Turkey, of all aspects of the Roman roads of Asia Minor: milestones, road surfaces, bridges, the imperial road stations and military installations. He combined his classical training with his archaeological experience and his intimate knowledge of Turkey to acquire a more profound understanding of the topographical history of Anatolia than any other scholar past or present. His passion for roads and routes extended from the Roman Empire back to its Hittite and Persian predecessors, and forward to the Ottoman period. At the start of his project, about 450 milestones were known from Asia Minor, by 2016 his own discoveries had raised this number to more than 1,200 . The research, carried out single-handed in the company of a series of Turkish representatives, was a perfect match for his skills and character. 
David French had a deep affection for Turkey and its people, above all in the villages and small towns of the Anatolian hinterland. A fine linguist, he mastered modern Greek and Turkish at the start of his career, and Turkey for much of his life was not merely an adopted but his real home. It is a matter of good fortune that he carried out much of his fieldwork before the accelerating developments of modern Turkey erased many traces of its historical heritage.

Internally, the BIAA had much to thank him for in these years. David conducted relationships with Turkish officialdom with candour, caution and old-fashioned politesse, that were universally respected. His main appointments in Ankara - of Ülge Göker and Gülgün Girdivan as managers of the Ankara office, of Yaprak Eran as librarian and the photographer Tuğrul Çakar - proved indispensable to the BIAA's stability. He was also an omnivorous and learned scholar, and the library was at the heart of his vision for the BIAA. Aided at the start by his first assistant director, Richard Harper, he transformed the library from being a modest adjunct to archaeological field expeditions into one of the two finest research collections for archaeology and related subjects in Turkey. The research collections of pottery from surveys, epigraphic squeezes, botanical specimens and animal bones were also largely his creations.

David French's long tenure of the BIAA directorship was more controversial than his reputation as a field archaeologist. He was a private man who did not court publicity or popularity. His preference for concisely establishing the facts as he saw them, rather than offering long explanations, was a feature of his correspondence as well as his academic publications, and could lead to misunderstandings. The loyalty and devotion that he won from his close associates were counterbalanced by his more abrupt style with those who knew him less well. The veteran archaeologists on the BIAA Council of Management did not hide their lack of sympathy for David's avant-garde Aşvan project, and subsequent relationships with some members of the Council were challenging. He did not cultivate close relations with British university archaeology departments, and this hampered the development of an overall excavation strategy for the BIAA. On the other hand, David enthusiastically supported the survey projects relating to historical periods by Clive Foss, Stephen Mitchell, James Coulton, Mark Whittow and others, which marked a major new departure in BIAA fieldwork. In this he owed much to the consistent support of a close friend, the epigrapher Alan Hall, BIAA honorary secretary from 1970 to 1985.

David's difficult relationship with the BIAA Council led him to take a year's study leave from the directorship in 1993 and then to stand down from his position. As a result, David, until the late 1990s, engaged little with the Institute. He was, however, now able to address the challenge of retirement with undiminished vigour and energy, enjoying his lifelong passions for early English music, birds and cricket as well as focusing on his academic interests. He recognised that he needed to publish the results of the Can Hasan excavations, and these duly appeared as three BIAA monographs between 1998 and 2010. He wrote many articles, the majority making known Greek and Latin inscriptions which he had recorded during his work on roads and routes. David's short book on the inscriptions of Ankara in 2003 led to renewed epigraphic collaboration with Stephen Mitchell in Ankara itself between 2004 and 2008, and the publication of the full corpus of Ankara's Roman and Byzantine inscriptions in two large volumes. However, the culmination of his life's work and his main published legacy takes the form of ten volumes (fascicules, as he always referred to them) in the series Roman Roads and Milestones of Asia Minor, produced in a phenomenal burst of energy between 2012 and 2016, and published on-line by the BIAA. Here too he could rely on devoted support from the draftsman Brian Williams and the IT and publication skills of Abby Robinson.

During these later years, he resolved his differences with the BIAA and was a regular visitor, usually en route in spring or autumn to the much-loved house near Anamur that he and his second wife Pamela had bought, at the suggestion of his Turkish friend and colleague Illhan Temizsoy. These were also working visits, which enabled him to undertake the cataloguing of the BIAA epigraphic squeeze collection and to bring order to the Institute's photographic archives.

His first marriage to Elizabeth Wace, daughter of A.J.B. Wace, who herself became director of the British School at Athens from 1989-1994, ended in divorce in 1976 , but they remained closely connected by their shared commitment to archaeology and in particular to continuing Wace's varied work in Greece. Near the end of his life, David completed a report on the pre-Mycenean pottery from Mycenae. David's second marriage was to Pamela Pratt, who had worked as conservator on the Çatalhöyük wall paintings and provided much appreciated expertise to the Ankara Museum. Although she did not engage in David's later field archaeological projects, her support, both before and after his retirement, was inestimably important to him. Both survive him, as do Ann and Catharine, the two daughters by his first marriage, John, his son by his second marriage, and four grandchildren.

I am grateful to members of David French's family and to Michele Massa for help with this obituary. 